\title{
Primary renal squamous cell carcinoma mimicking the renal cyst: a case report and review of the recent literature
}

\author{
Peng Jiang ${ }^{1}$, Chaojun Wang ${ }^{1}$, Shanwen Chen ${ }^{1}$, Jun Li ${ }^{2}$, Jianjian Xiang ${ }^{3 *}$ and Liping Xie ${ }^{1 *}$
}

\begin{abstract}
Background: Renal squamous cell carcinoma is a rare neoplasm with poor prognosis. Chronic irritation from nephrolithiasis and/or pyelonephritis is the leading cause.

Case presentation: We described a 51-year-old male patient who was admitted because of left flank pain. Ultrasonography showed a renal cyst containing calculus. However, contrast-enhanced ultrasonography and CT scan revealed an irregular-shaped mass derived from a calculi-containing cyst. Ultrasound guided biopsy confirmed the diagnosis of renal squamous cell carcinoma. The patient refused any further therapeutic management and died six months later.
\end{abstract}

Conclusions: Our present case emphasizes that the careful diagnostic work-up and use of multiple imaging modalities in cases of unusual renal calculi is quite necessary, since they may carry the risk of co-existing hidden malignancy.

Keywords: Kidney, Squamous cell carcinoma

\section{Background}

Squamous cell carcinoma (SCC) of the renal pelvis is a rare neoplasm, accounting only 0.5 to $0.8 \%$ of malignant renal tumors [1]. The predisposing factors leading to development of SCC of the renal pelvis include renal calculi, infections, endogenous and exogenous chemicals, vitamin A deficiency, hormonal imbalance and radiotherapy [2-4]. We reported a case of primary SCC of the renal pelvis, which was unsuspected before biopsy, and the most recent related literatures were reviewed as well.

\section{Case presentation}

An otherwise healthy 51-year-old male suffering from persist left flank pain for one week and was referred to the urology department. Physical examination revealed mild left costovertebral angle tenderness but was otherwise normal. Routine diagnostic work-up including chest

\footnotetext{
* Correspondence: ultraxjj@126.com; xielp@zju.edu.cn

${ }^{3}$ Department of Ultrasonography, The First Affiliated Hospital, School of Medicine, Zhejiang University, Hangzhou, Zhejiang Province, China

'Department of Urology, The First Affiliated Hospital, School of Medicine,

Zhejiang University, Qingchun Road 79, Hangzhou 310003, Zhejiang

Province, China

Full list of author information is available at the end of the article
}

$\mathrm{X}$-ray and laboratory investigations were all within the normal range, but ultrasonography revealed a renal cyst containing calculus. Further computed tomography (CT) of the kidneys revealed an irregular-shaped homogeneous mass derived from the cyst was found. The mass enveloped the renal pedicle, aorta and inferior vena cava (Fig. 1). The mass was biopsied percutaneously under ultrasonographic guidance. The histological examination revealed squamous cell carcinoma (Fig. 2). Considering that the mass was un-resectable, the patient refused any other treatment. He returned to home hospice and unfortunately died six months later.

\section{Discussion}

The kidney is an unusual site for SCC. Renal SCC, most of which is known to arise from collecting system, is a rare clinical entity representing only 0.5 to $0.8 \%$ of malignant renal tumors [1]. It usually occurs in late adulthood and is reported of an equal incidence in men and women [5]. However, according to the recent literatures (Table 1), men bear a higher incidence of renal SCC, probably because of higher incidence of nephrolithiasis in men [2, 6-20]. Long-standing nephrolithiasis and/or chronic pyelonephritis are the most common causes for 


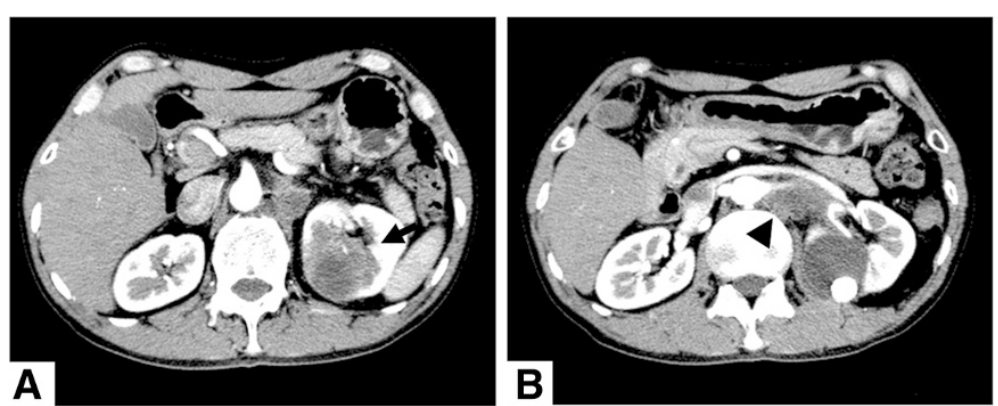

Fig 1 CT showed an irregular-shaped homogeneous mass (arrow) derived from the cyst and enveloped the renal pedicle

renal SCC. Other potential etiology have been described in the literatures, including exogenous and endogenous chemicals (e.g. arsenic), vitamin A deficiency, and prior surgery for renal stones, analgesic abuse, radiotherapy or chronic rejection in a transplant kidney [2-4]. Chronic irritation can cause squamous metaplasia of the renal collecting system, which may subsequently progress to leukoplakia and neoplasia of the urothelium, resulting in SCC of the renal pelvis. In our case, we speculated that the tumor has arisen in a chronically inflamed hydronephrotic calyx or a calyceal diverticulum with long term irritation by calculi.

Patients with renal SCC may present with flank or abdominal pain, microscopic or gross hematuria, fever, weight loss or a palpable abdominal mass (Table 1). It could also be the incidental finding on radiographic imaging for other reasons. Establishing the diagnosis of renal SCC by imaging techniques before biopsy or surgery is a clinical dilemma. Conventional ultrasonography is the choice of imaging modality for renal diseases evaluation, but renal SCC lacks specific echoic pattern

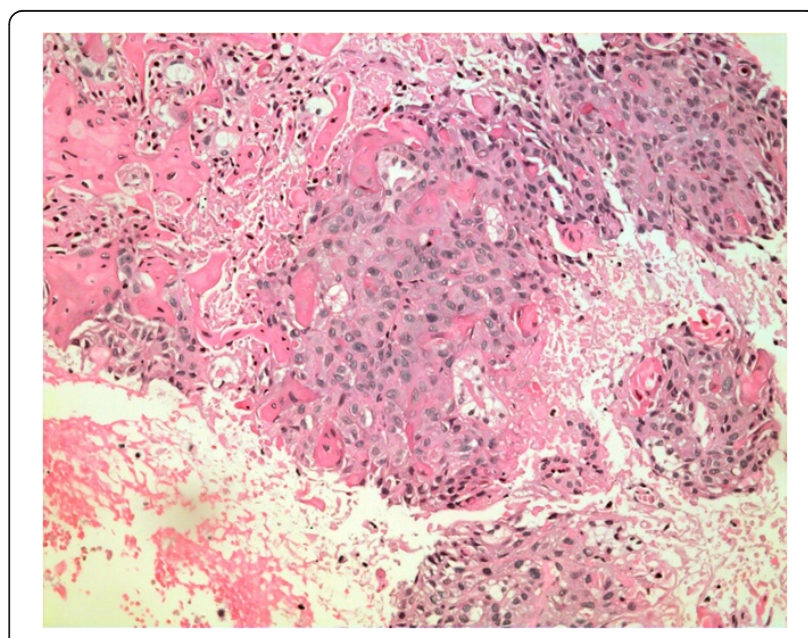

Fig 2 Biopsy pathology showing a high power view of squamous cell carcinoma (H\&E x200) in ultrasonography. Real-time CEUS was supposed to provide additional information for improving the diagnosis [21]. CT may play a crucial role in diagnosis and staging of the tumor. The radiologic evidences of renal SCC are diverse and may appear as a solid mass with irregular shape, hydronephrosis, calcifications, or as a renal pelvic infiltrative lesion without evidence of a distinct mass. The most helpful feature in CT of renal SCC is presence of enhancing extra-luminal and exophytic mass in some cases, with an intra-luminal component [16]. Lack of specific clinical and radiologic features in renal SCC would result in diagnostic confusion. Thus, the precise histological diagnosis was usually established after nephrectomy. For the un-resectable cases, both endoscopic and percutaneous biopsy could be applied to obtain the specimen. In our case, we chose ultrasoundguided biopsy because the CT scan presented the feature of extensive peritumoral vascular invasion, which indicated that the tumor was un-resectable.

Surgical resection is regarded as the mainstay of treatment for renal SCC [18]. However, the renal SCC is aggressive in nature and concealed. Most cases usually present at an advanced stage-pT3 or higher [16]. Therefore, for the treatment of advanced disease, a multidisciplinary approach comprising of surgical treatment and adjuvant chemoradiotherapy should be applied. Still, the prognosis of renal SCC is generally poor. According to the literatures, the outcome of renal SCC is dismal with a median survival of only several months postoperatively. Holmäng et al. reported that the prognosis of renal SCC is usually poor with a mean survival period of 7 months [5]. The 5-year survival rate is reported less than $10 \%$ [14]. Thus, early diagnosis, monitoring of patients with longstanding nephrolithiasis, and new treatment modalities are urgently needed to improve patients' outcomes.

\section{Conclusions}

For patient with unusual renal calculi, the careful diagnostic work-up with multiple imaging modalities should be applied to exclude the co-existing hidden malignancy. 
Table 1 Characteristics of the reported cases from recent 5 years

\begin{tabular}{|c|c|c|c|c|c|c|}
\hline Author & Sex & Age & Presentation & Ultrasonographic/radiological feature & Treatment & Prognosis \\
\hline $\begin{array}{l}\text { Bandyopadhyay } \\
\text { et al. [6] }\end{array}$ & M & 58 & $\begin{array}{l}\text { Heaviness and swelling in } \\
\text { the left upper abdomen }\end{array}$ & Hydronephrosis & Nephrectomy & $N / A^{a}$ \\
\hline Imriaco et al. [7] & M & 69 & Left flank abdominal pain & $\begin{array}{l}\text { A solid mass within the left side of a horseshoe } \\
\text { kidney, with associated large renal stones }\end{array}$ & Partial left nephrectomy & N/A \\
\hline Mathur et al. [20] & M & 52 & $\begin{array}{l}\text { Heaviness and swelling in } \\
\text { the left upper abdomen }\end{array}$ & Non-functional kidney with dilation of renal calyces & Nephrectomy & N/A \\
\hline \multirow[t]{4}{*}{ Jain et al. [10] } & M & 50 & Right flank pain & Staghorn calculi with right renal hydronephrosis & Nephrectomy & N/A \\
\hline & M & 87 & Left lower abdomen pain & $\begin{array}{l}\text { Left nephrolithiasis with staghorn calculi and } \\
\text { hydronephrosis }\end{array}$ & Nephrectomy & Die in hospital because of coronary complication \\
\hline & $\mathrm{F}$ & 50 & Left flank pain & $\begin{array}{l}\text { Left renal and ureteric calculi with absence of } \\
\text { corticomedullary distinction }\end{array}$ & $\begin{array}{l}\text { Nephrectomy + cisplatin- } \\
\text { based chemotherapy }\end{array}$ & Alive at 3 months after surgery \\
\hline & M & 53 & Bilateral flank pain & Right renal calculi with hydronephrosis & $\begin{array}{l}\text { Nephrectomy + cisplatin- } \\
\text { based chemotherapy }\end{array}$ & Alive at 5 months after surgery \\
\hline Paonessa et al. [11] & $\mathrm{F}$ & 70 & Vague abdominal pain & $\begin{array}{l}\text { Multiple calcified areas within superior pole of } \\
\text { the left kidney }\end{array}$ & Nephrectomy & N/A \\
\hline Baseskioğlu et al. [13] & M & 56 & Left flank pain and fever & Hydronephrosis, staghorn calculi & Nephrectomy + radiation & Local recurrence, died 3 years later \\
\hline Verma et al. [12] & M & 62 & $\begin{array}{l}\text { Intermittent colicky pain at } \\
\text { the right lumbar region }\end{array}$ & Right pyonephrosis with nephrolithiasis & $\begin{array}{l}\text { Pyelithotomy (Palliative) + } \\
\text { chemotherapy }\end{array}$ & N/A \\
\hline Ham et al. [15] & M & 69 & $\begin{array}{l}\text { Swelling and pain of right } \\
\text { upper abdomen }\end{array}$ & Severe hydronephrosis with calyceal stones & Nephrectomy + Chemo & Died 7 months later \\
\hline Bhaijee [14] & $\mathrm{F}$ & 77 & $\begin{array}{l}\text { Weight loss and severe } \\
\text { anemia }\end{array}$ & $\begin{array}{l}\text { Left upper pole renal mass, staghorn calculus and } \\
\text { renal vein thrombus }\end{array}$ & Nephrectomy & $\begin{array}{l}\text { Asymptomatic with no evidence of recurrent or } \\
\text { metastatic disease } 6 \text { months after surgery }\end{array}$ \\
\hline Kalayci et al. [16] & M & 63 & $10 \mathrm{~kg}$ weight loss & $\begin{array}{l}\text { Big, non-functioning right kidney with staghorn calculi } \\
\text { and a hypodense mass within the renal parenchyma } \\
\text { extending to the upper pole of the right kidney }\end{array}$ & Nephrectomy & N/A \\
\hline Palmer et al. [17] & $\mathrm{F}$ & 46 & Incidental finding & $\begin{array}{l}\text { Large Coarse calculi with dilated renal collecting } \\
\text { systems }\end{array}$ & Nehprectomy & Died on postoperative day 8 \\
\hline Wu et al. [19] & M & 66 & $\begin{array}{l}\text { Intermittent melena, nausea, } \\
\text { malaise, and abdominal pain }\end{array}$ & $\begin{array}{l}\text { Heterogeneous renal mass containing a staghorn } \\
\text { stone }\end{array}$ & $\begin{array}{l}\text { Exploratory operation }+ \\
\text { biopsy }\end{array}$ & Died less than 5 months \\
\hline Lin et al. [18] & M & 56 & Hematuria & Right renal staghorn calculi & Debulking surgery & $\begin{array}{l}\text { Asymptomatic with no evidence of recurrent } \\
\text { or metastatic disease } 6 \text { months after surgery }\end{array}$ \\
\hline Hameed et al. [2] & F & 41 & $\begin{array}{l}\text { Chronic backache in the } \\
\text { right gluteal region }\end{array}$ & $\begin{array}{l}\text { Complete staghorn calculus with sacral bone } \\
\text { metastasis }\end{array}$ & Chemotherapy & $\begin{array}{l}\text { Died } 2 \text { weeks after the } 3 \text { rd cycle of } \\
\text { chemotherapy }\end{array}$ \\
\hline
\end{tabular}




\section{Consent}

Written informed consent was obtained from the patient for publication of this case report and any accompanying images.

\section{Abbreviations}

SCC: Squamous cell carcinoma; CEUS: Contrast-enhanced ultrasonography; $\mathrm{CT}$ : Computed tomography.

\section{Competing interests}

The authors declare that they have no competing interests.

\section{Authors' contributions}

PJ and JJX drafted the manuscript. JJX provided imaging description and figures. CJW, SWC and JL assisted with manuscript preparation and literatures collection. LPX revised the manuscript. All authors have read and approved the final manuscript.

\section{Author details}

'Department of Urology, The First Affiliated Hospital, School of Medicine, Zhejiang University, Qingchun Road 79, Hangzhou 310003, Zhejiang Province, China. ${ }^{2}$ Department of Pathology, The First Affiliated Hospital, School of Medicine, Zhejiang University, Hangzhou, Zhejiang Province, China. ${ }^{3}$ Department of Ultrasonography, The First Affiliated Hospital, School of Medicine, Zhejiang University, Hangzhou, Zhejiang Province, China.

Received: 6 December 2014 Accepted: 6 July 2015

Published online: 23 July 2015

\section{References}

1. Li MK, Cheung WL. Squamous cell carcinoma of the renal pelvis. J Urol. 1987;138(2):269-71.

2. Hameed ZB, Pillai SB, Hegde P, Talengala BS. Squamous cell carcinoma of the renal pelvis presenting as sacral bone metastasis. BMJ Case Rep. 2014:2014. doi:10.1136/bcr-2013-201719.

3. Schena S, Bogetti D, Setty S, Kadkol S, Bruno A, Testa G, et al. Squamous cell carcinoma in a chronically rejected renal allograft. Am J Transplant. 2004;4(7):1208-11.

4. Papadopoulos I, Wirth B, Weichert-Jacobsen K, Loch T, Wacker HH. Primary squamous cell carcinoma of the ureter and squamous adenocarcinoma of the renal pelvis: 2 case reports. J Urol. 1996;155(1):288-9.

5. Holmang S, Lele SM, Johansson SL. Squamous cell carcinoma of the renal pelvis and ureter: incidence, symptoms, treatment and outcome. J Urol. 2007;178(1):51-6.

6. Bandyopadhyay R, Biswas S, Nag D, Ghosh AK. Squamous cell carcinoma of the renal pelvis presenting as hydronephrosis. J Cancer Res Ther. 2010;6(4):537-9.

7. Imbriaco M, lodice D, Erra P, Terlizzi A, Di Carlo R, Di Vito C, et al. Squamous cell carcinoma within a horseshoe kidney with associated renal stones detected by computed tomography and magnetic resonance imaging. Urology. 2011;78(1):54-5

8. Soni HC, Jadav VJ, Sumariya B, Venkateshwaran KN, Patel N, Arya A. Primary malignancy in crossed fused ectopic kidney. Abdom Imaging. 2012;37(4):659-63.

9. Hsieh TC, Wu YC, Sun SS, Chiang IP, Yang CF, Yen KY, et al. Synchronous squamous cell carcinomas of the esophagus and renal pelvis. Clin Nucl Med. 2011;36(11):e171-174.

10. Jain A, Mittal D, Jindal A, Solanki R, Khatri S, Parikh A, et al. Incidentally detected squamous cell carcinoma of renal pelvis in patients with staghorn calculi: case series with review of the literature. ISRN Oncol. 2011;2011:620574.

11. Paonessa J, Beck H, Cook S. Squamous cell carcinoma of the renal pelvis associated with kidney stones: a case report. Med Oncol. 2011;28 Suppl 1:\$392-394.

12. Verma N, Yadav G, Dhawan N, Kumar A. Squamous cell carcinoma of kidney co-existing with renal calculi: a rare tumour. BMJ Case Rep. 2011:2011.

13. Baseskioglu B, Yenilmez A, Acikalin M, Can C, Donmez T. Verrucous carcinoma of the renal pelvis with a focus of conventional squamous cell carcinoma. Urol Int. 2012;88(1):115-7.
14. Bhaijee F. Squamous cell carcinoma of the renal pelvis. Ann Diagn Pathol. 2012;16(2):124-7.

15. Ham BK, Kim JW, Yoon JH, Oh M, Bae JH, Park HS, et al. Squamous cell carcinoma must be considered in patients with long standing upper ureteral stone and pyonephrosis. Urol Res. 2012;40(4):425-8.

16. Kalayci OT, Bozdag Z, Sonmezgoz F, Sahin N. Squamous cell carcinoma of the renal pelvis associated with kidney stones: radiologic imaging features with gross and histopathological correlation. J Clin Imaging Sci. 2013;3:14.

17. Palmer CJ, Atty C, Sekosan M, Hollowell CM, Wille MA. Squamous cell carcinoma of the renal pelvis. Urology. 2014;84(1):8-11.

18. Lin Z, Chng JK, Chong TT, Soo KC. Renal pelvis squamous cell carcinoma with inferior vena cava infiltration: Case report and review of the literature. Int J Surg Case Rep. 2014;5(8):444-7.

19. Hui Wu J, Xu Y, Qiang Xu Z, Yang K, Qiang Yang S, Shun Ma H. Severe anemia and melena caused by pyeloduodenal fistula due to renal stoneassociated squamous cell carcinoma. Pak J Med Sci. 2014;30(2):443-5.

20. Mathur S, Rana P, Singh S, Goyal V, Sangwan M. Incidentally detected squamous cell carcinoma in non-functioning kidney presenting as multi-cystic mass. J Surg Case Rep. 2011;9:8.

21. Li X, Liang P, Guo M, Yu J, Yu X, Cheng Z, et al. Real-time contrast-enhanced ultrasound in diagnosis of solid renal lesions. Discov Med. 2013;16(86):15-25.

\section{Submit your next manuscript to BioMed Central and take full advantage of:}

- Convenient online submission

- Thorough peer review

- No space constraints or color figure charges

- Immediate publication on acceptance

- Inclusion in PubMed, CAS, Scopus and Google Scholar

- Research which is freely available for redistribution 